IZA DP No. 3662

\title{
New Evidence on the Motherhood Wage Gap
}

\section{Catalina Amuedo-Dorantes} J ean Kimmel

August 2008 


\title{
New Evidence on the Motherhood Wage Gap
}

\author{
Catalina Amuedo-Dorantes \\ San Diego State University \\ and IZA \\ Jean Kimmel \\ Western Michigan University \\ and IZA
}
Discussion Paper No. 3662
August 2008

IZA
P.O. Box 7240
53072 Bonn
Germany

Phone: +49-228-3894-0

Fax: +49-228-3894-180

E-mail: iza@iza.org

\begin{abstract}
Any opinions expressed here are those of the author(s) and not those of IZA. Research published in this series may include views on policy, but the institute itself takes no institutional policy positions.

The Institute for the Study of Labor (IZA) in Bonn is a local and virtual international research center and a place of communication between science, politics and business. IZA is an independent nonprofit organization supported by Deutsche Post World Net. The center is associated with the University of Bonn and offers a stimulating research environment through its international network, workshops and conferences, data service, project support, research visits and doctoral program. IZA engages in (i) original and internationally competitive research in all fields of labor economics, (ii) development of policy concepts, and (iii) dissemination of research results and concepts to the interested public.
\end{abstract}

IZA Discussion Papers often represent preliminary work and are circulated to encourage discussion. Citation of such a paper should account for its provisional character. A revised version may be available directly from the author. 
IZA Discussion Paper No. 3662

August 2008

\section{ABSTRACT}

\section{New Evidence on the Motherhood Wage Gap}

Using data from the 1979 National Longitudinal Survey of Youth, we assess the role of employment-based health insurance offers in explaining the motherhood wage gap. Researchers have been aware of the existence of a motherhood gap for many years; yet, the literature has failed to address the role of non-wage compensation in explaining the motherhood wage gap despite the increasing importance of non-wage benefits in total compensation packages. As hedonic wage theory suggests, mothers might view health benefits as desirable and trade-off wages for health insurance. Thus, lower wages for mothers might reflect their relative preferences for jobs offering health insurance. We estimate an endogenous switching wage equation model to account for the self-selection and, thus, endogeneity of having an employment-based health insurance offer. We find that, once the endogeneity of having an employment-based health insurance offer is accounted for, the motherhood wage gap disappears.

JEL Classification: J01, J31, J33, J16

Keywords: motherhood wage gap, non-wage compensation, health insurance

Corresponding author:

Catalina Amuedo-Dorantes

Department of Economics

San Diego State University

5550 Campanile Drive

San Diego, CA 92182

USA

E-mail: camuedod@mail.sdsu.edu 


\section{Introduction}

For many years, researchers have been aware of the so-called motherhood wage gap: the empirical fact that mothers earn less than non-mothers, even when relevant productivity factors are taken into account. In this vein, Waldfogel (e.g., 1997) has estimated this gap in the range of 5 to 15 percent. Amuedo-Dorantes and Kimmel (2005) have shown that the motherhood wage penalty is experienced to a greater extent by lesser-educated mothers and that it can be mitigated by fertility delay. Likewise, Anderson et al. (2002 and 2003) have discussed the importance of mothers' education, along with their timing in returning to work post-childbirth, in explaining the motherhood wage penalty. Yet, while there exists a vast literature examining differences in monetary wage compensation according to motherhood status, very little attention has been paid to the role played by non-wage benefits in explaining the motherhood wage penalty. As hedonic wage theory suggests, mothers might view health benefits as desirable and, therefore, be willing to trade-off wages for the possibility of having health insurance coverage through their jobs. Thus, lower wages for mothers might reflect their preferences for non-wage compensation.

Using NLSY79 data, we assess the trade-off between wages and the offer of employment-based health insurance coverage by motherhood status. We estimate an endogenous switching model that allows for the stratification of wages according to whether the respondent receives an employment-based health insurance offer to assess the role played by non-wage benefits in explaining the motherhood wage gap. In addition to accounting for a different wage structure in jobs depending on whether they offer health insurance, the model allows us to address the endogeneity of having an employment-based health insurance offer with respect to wages -partially originating in the self-selection of women into a particular type of job. The analysis herein allows us to gauge the role played by non-wage compensation in the 
motherhood wage penalty and, as such, provides valuable insights into the sources of the motherhood wage gap.

\section{Gender Differences and the Motherhood Wage Gap}

Evidence of lower wages for mothers has been noted in the economics literature for nearly 30 years, starting with Hill (1979). Current discussion of the motherhood wage gap is most appropriate given the trend noted by Waldfogel (1998) in the overall gender wage gap and the family wage gap component. Specifically, she notes that, while the gender wage gap has fallen in recent years, the motherhood wage gap has actually increased. Comparing the ratios of mean hourly wages by sex and motherhood status, Waldfogel reports that the ratio of nonmothers' wages to all men’s wages rose from 68.4 percent in 1978 to 81.3 percent in 1994, whereas the ratio of mothers' wages to all men’s wages rose by less, from 62.5 percent to 73.4 percent over the same period (Table 4, pg. 144). Using regression techniques, Waldfogel shows that the role of family (i.e., marital and motherhood status) accounted for 35 percent of the gender wage gap in 1980 and increased to 56 percent of the gap in 1991 (pg. 148).

Researchers have offered a variety of explanations for the existence of this family wage gap, which is estimated to be in the range of 5 to 15 percent. ${ }^{1}$ Waldfogel (1998) discusses three reasons: unobserved heterogeneity, discrimination, and institutional features of the labor market. Perhaps most important is the role of previous intermittent work in determining this gap, as incorporating direct measures of continuous work history reduces the estimated gap. Anderson et al. (2003) note that work history explains a large portion of the motherhood wage gap. Likewise, this gap might also be reduced if labor market institutions in the United States were

\footnotetext{
${ }^{1}$ In studies of the motherhood wage gap, researchers either model motherhood with a 0-1 dummy variable or with two separate dummy variables, one indicating the presence of just one child in the family and one indicating two or more children in the family.
} 
more amenable to working mothers, as it appears to be the case in other developed countries. For example, Todd (2001) notes lower family gaps in European countries. Another explanation for the motherhood wage gap is one of reduced effort on the part of mothers; however, Anderson et al. (2002) reject this hypothesis as a major contributor to the gap. Finally, Budig and England (2001) conclude that the most important likely contributors to the motherhood wage gap are diminished productivity and discrimination.

Numerous methodological concerns arise when deriving numerical estimates of the motherhood wage gap, including unobserved heterogeneity, selection into employment (as unobservables in this choice are likely highly correlated with the decision to become a mother), and endogeneity concerns with respect to experience, tenure, and motherhood status. For instance, Waldfogel (1998) notes that unobserved heterogeneity may play a role in explaining the motherhood wage gap; thus suggesting the need to use panel data. Yet, the use of panel data methods does not seem to eliminate the existence of a motherhood wage gap (e.g. AmuedoDorantes and Kimmel 2005). Neumark and Korenman (1992) go one step further and, after correcting for potential endogeneity issues, still produce a positive estimate of the motherhood wage gap. Likewise, Amuedo-Dorantes and Kimmel (2005) estimate a variety of specifications, some of which correct for the endogeneity of motherhood, and still find evidence of the motherhood wage gap.

Amuedo-Dorantes and Kimmel (2005) also document a puzzling finding. They estimate the motherhood wage gap for women with different educational attainment and find that the regression-adjusted motherhood wage differential is actually positive for women with four or more years of post-high school education. This wage boost at higher levels of education, which 
has also been documented by others in the literature, ${ }^{2}$ is possibly based on mothers' (or future mothers') incentive to identify family friendly employers who offer benefits, such as flexible work schedules or generous maternity leaves. By identifying these workplaces based on readily observable job characteristics, they are inadvertently choosing "female-friendly" employers less likely to discriminate against women. As such, college-educated childless women may be, in comparison, doing themselves a disservice by avoiding family-friendly employers, resulting in lower wages than college-educated mothers, ceteris paribus.

\section{The Role of Non-wage Compensation in Explaining Wage Gaps}

The literature on the gender and motherhood wage gap has primarily focused on earnings and, significantly less, on non-wage benefits. The exclusion of non-wage benefits in the discussion of the gender and, in particular, the motherhood wage gap has become more problematic in recent years as the percentage of total compensation captured by wages has declined to approximately 71.4 percent in the year 2003 (Levy, pg. 15, 2006) from 95.1 percent in 1966 (Woodbury, pg. 166, 1983). Thus, non-wage benefits are playing an ever bigger role in workers' compensation packages. Clearly, factors other than wages are important determinants of total compensation, suggesting that they are likely to also play an important role in the worker/job sorting process. The theory of compensating wage differentials asserts that workers (and firms) trade-off wage and non-wage benefits when searching for the optimal job offer package. $^{3}$ However, empirical evidence of such trade-offs using micro-level data has been inconsistent at best.

\footnotetext{
${ }^{2}$ See, for example, Taniguchi (1999), Todd (2001) and Blackburn et al. (1990).

${ }^{3}$ Woodbury (1983) develops a theoretical model to test the willingness and ability of workers to trade wage and non-wage benefits in the total compensation package. He finds that wages and fringes are substituted in the total compensation package with ease. Likewise, B.K. Atrostic
} 
A variety of studies have examined the role played by non-wage benefits on wage gaps. For example, Filer (1985) presents an early look at the role of compensating wage differentials in explaining gender wage gaps, with a focus on non-pecuniary job characteristics such as task redundancy, prospects for promotion, and job hazards. He does not focus directly on health insurance benefits, preferring instead to include monetarily measurable benefits in his measure of compensation. Filer's results show a 24 percent reduction in the female "wage penalty" when this hedonic model is incorporated.

More recently, a variety of studies have directly addressed the role played by health benefits in explaining wage gaps among all workers. In this regard, Gruber (1994) relies on the exogenous differential timing across states in the passage of laws mandating that employerprovided health plans cover pregnancy-related costs to identify a wage-fringe trade-off. He finds that workers most likely to benefit from these laws did earn lower wages. Likewise, Currie and Madrian (1999), in their extensive review of the health insurance and labor markets, discuss the existing evidence on the relationship between wages and health insurance in the labor market. They argue that relying on firm-level data will reveal a positive relationship between wages and fringes because higher productivity workers tend to be paid higher wages and receive more generous fringe benefits. In other words, the labor market consists of "good” jobs and "bad" jobs. Using individual-level data with appropriate controls for ability can reduce this statistical problem. However, the use of panel data may not totally circumvent the remaining omitted ability bias. To the extent that some of the variability in fringe benefits is due to job changes, treatment of the job change mechanism and the wage-fringe trade-off becomes important. Monheit and Vistnes (1999) seem in agreement with Currie and Madrian, finding evidence of

(1982) makes an important contribution to this literature, focusing on non-pecuniary non-wage benefits (such as on-the-job risk or physical comfort). 
individual worker preferences for health insurance driving worker sorting into jobs with and without such offers, but Lehrer and Pereira (2007) find no evidence of a health insurance compensating differential in their study of displaced workers.

There has been some success in recent years in establishing empirically a wage-fringe trade-off by researchers focusing on narrower groups of workers. Adams (2007) addresses the difficulty of dealing with the "good jobs versus bad jobs" problem by focusing on older workers in New York State during a period of policy transition. ${ }^{4}$ The new policy only allowed for regional differences in health care costs to be considered when setting health insurance premiums, while risk factors, such as age, could no longer be incorporated in the calculation of such premiums. The focus on older workers is particularly useful because age is an extremely easy-to-identify risk factor associated with higher health expenditures. Thus, if age is eliminated from the legal criteria that can be used to set insurance premiums, one would expect older workers' wages to decrease when workers and firms trade-off wage and non-wage benefits. ${ }^{5}$ We modify Adams' approach in two ways. First, he relies on CPS data, but the CPS reports only actual employer-provided health insurance coverage. We, instead, focus on employer-provided health insurance offers. These two concepts may vary in some systematic way due to individual differences in the incentive to take-up coverage. Second, we consider the likely endogeneity of health insurance coverage.

Focused on gender wage differentials, recent research has incorporated health insurance coverage information in studies of the gender wage gap. For example, Levy (2006) presents a detailed examination of the role played by health insurance in the gender wage gap, including

\footnotetext{
${ }^{4}$ Sheiner (1999), focusing on older workers, also finds results that support the notion of a wagefringe trade-off.

${ }^{5}$ Adams (2007) explains the difficulty in explaining the wage-age profile because of evidence that the steep upward slope of this profile results from more than returns to experience.
} 
specific attention to employer health insurance offers, workers' eligibility for such offers, and finally, worker take-up of coverage. Levy concludes that measuring the gender compensation gap including health insurance coverage would reduce estimates of sex compensation inequality. Her findings indicate the importance of broadening gender compensation gap studies to address more than just wage differentials. In contrast, McCrate (2005) examines non-wage job characteristic of flexible work schedules; but only finds weak support for compensating differentials as an explanation for the gender wage gap.

Only recently have researchers begun to explore the possibility of an explicit link between the motherhood wage gap and employers' provision of a variety of family-friendly benefits (other than health care insurance). In this vein, Felfe (2007) examines job changes surrounding a mother's birth of her first child and explains that there are some systematic patterns in benefit changes associated with childbirth. She argues that direct evidence of this trade-off can be found in her estimated wage regressions, which include family-friendly job characteristics as exogenous regressors. However, because of the likely endogeneity of these benefits, this evidence remains only suggestive. In fact, also focusing on the motherhood wage gap, Amuedo-Dorantes and Kimmel (2005) are unable to find evidence of a compensating wage differential. Instead, they uncover a positive correlation between family-friendly benefits and wages, which could be due to a possible link between an employer's provision of family-friendly benefits and female-friendly management.

To our knowledge, the best approach to examining whether mothers accept lower wages in order to attain jobs in more family-friendly workplaces is found in Nielsen et al. (2004). ${ }^{6}$ In

\footnotetext{
${ }^{6}$ Budig and England (2001) include family-friendly job characteristics in their estimation to address the role of compensating differentials in producing the motherhood wage gap and find
} 
this paper, the authors note that the public sector in Sweden is well-known for its relatively generous non-wage benefits and lower pay rates. They test the existence of a compensating wage differential among mothers by means of an endogenous switching model in which the observed switching mechanism is the choice of private versus public sector. Our approach differs in our choice to focus directly on a specific family-friendly job characteristic (namely, the health insurance offer) rather than on a more indirect set of job characteristics embedded in public sector employment. After all, in the U.S., public sector employment is only loosely associated at best with non-wage benefits (i.e., not all public sector jobs are “good” jobs).

\section{Data}

We draw our data from the 1979 National Longitudinal Survey of Youth (NLSY79). We use a non-balanced panel of women that, as of 2004, contained approximately 1,839 women employed in the private sector. The best measure of health insurance coverage for this estimation would be the precise dollar value of the offered health benefit package, information unavailable in most survey data sets. However, the NLSY data contain a self-reported variable that equals one if the worker has health insurance available from her employer. Using this information to construct our dummy variable indicator for the employer offer of health insurance coverage reveals that approximately 78 percent of working women in our sample had an employer health insurance offer as of 2004. This health insurance coverage offer is distinct from actual coverage, which, in addition, reflects a take-up decision. This distinction is important since, as noted by Levy (2006), women are much more likely than men to decline employer offers of health insurance coverage.

that these characteristics are not associated with the lower wages earned by mothers. Their approach, however, does not address the endogeneity of these job features. 
Table 1 provides some of these women's characteristics according to whether or not they were offered health insurance through their employers. As it is typically the case with other datasets, women with health care insurance offers earned substantially more per hour than their counterparts lacking such offers (\$9.68 versus \$5.87), reflecting the good job versus bad job heterogeneity discussed earlier. Their ages are quite similar, with an average of approximately 43 years, as is also their racial distribution. Perhaps one of the most interesting facts is that a higher percentage of women lacking a health insurance offer through their employer display health related work limitations. Not surprisingly, the lack of an employer health insurance offer is more prominent among less educated women, with less tenure in their jobs, and with fewer skills as reflected by their occupations. Finally, working women in urban areas appear slightly less likely to lack health insurance through their employers.

To provide further descriptive evidence of the motherhood wage gap, we present in Table 2 calculations of the relative impact of receiving a health insurance offer on the motherhood wage gap. This estimate is calculated by:

(1) $\quad \Delta_{\text {HCI }}^{2}=\left(w_{\text {Non-mothers }}^{A}-w_{\text {Non-mothers }}^{B}\right)-\left(w_{\text {Mothers }}^{A}-w_{\text {Mothers }}^{B}\right)$

where $w_{j}{ }^{i}$, is the log real hourly wage earned by group $j$ when belonging to a particular type of job $i$ ( $\mathrm{A}=$ jobs offering health insurance, $\mathrm{B}=$ jobs not offering health insurance). From the calculations in Table 2, it is clear that wages differ by motherhood status only for those mothers in jobs with health insurance offers, whereas they do not among mothers lacking this non-wage benefit. As a result, the motherhood wage gap among women with employer-based health insurance offers is 13 percentage points larger than among their counterparts lacking such job benefit. This descriptive evidence is consistent with the compensating wage differential story of 
the motherhood wage gap and persists even when we use an alternative definition of motherhood to differentiate between mothers with one kid versus mothers with two or more children.

At any rate, it is worth noting that the double difference estimate from the above calculation is based on the assumption that women with and without employer-based health insurance offers are similar. Yet, we know that they may differ in some respects. Therefore, an alternative estimate that adjusts for the selection into jobs offering employer-based health insurance as well as for other differences in observable characteristics is discussed in the following section.

\section{Methodology}

Our interest is to examine the potential role of having a health insurance offer from the employer in explaining the motherhood wage gap. With that purpose in mind, we could estimate the following model:

$$
\ln w_{i}=X_{i} \beta+\delta \operatorname{mom}_{i}+\phi h i_{i}+\varphi\left(\operatorname{mom}_{i} * h i_{i}\right)+\varepsilon_{i}
$$

where $X$ would be a vector of human capital descriptors, job characteristics, and regional controls. The variable mom would equal 1 if the woman is a mother and zero otherwise, whereas hi would equal 1 if the worker received a health insurance offer from her employer. The parameter $\delta$ would capture the motherhood wage gap for mothers lacking employment-based health insurance offers, $\phi$ would denote the extent to which non-mothers trade wages for health insurance offers at work, and the sum $(\phi+\varphi)$ would capture the motherhood wage gap among women who have been offered health insurance coverage through their jobs. Note, however, that the estimates in equation (2) would be biased for three reasons. First, hedonic wage theory suggests that women may self-select themselves into a particular job depending on their preference for wage versus non-wage compensation. Second, wages and health insurance offers 
made by employers are likely to be determined jointly and, as such, having a health insurance offer is likely to be endogenous to wages. Endogeneity of a health insurance offer can also occur if unobserved characteristics influencing the likelihood of receiving a health insurance offer also affect the wage earned once employed. A third problem with specification (2) is the possible existence of a differing wage structure for women in "good" jobs offering health insurance versus women in "bad" jobs lacking any health insurance offer, as argued by segmented labor market theory.

In order to address the aforementioned limitations, we estimate an endogenous switching model that examines the wage earned by women in two separate equations according to whether or not they received a health insurance offer from their employer (Maddala 1983). In addition to allowing for a different wage structure depending on whether the job offers health insurance or not, we are able to model women's self-selection into jobs offering health insurance and, as such, the endogeneity of having a health insurance offer from the employer with respect to wages. Neglecting this self-selection of women into specific jobs and, thus, the endogeneity of having a health insurance offer, would yield biased estimates of the importance of non-wage benefits in the motherhood wage gap. Our full model would thus be given by:

(3) $\quad \ln w_{1 i}=X_{i} \beta_{1}+\delta_{1} m o m_{i}+\varepsilon_{1 i}$ if $h i_{i}^{*}>0$, and

(4) $\quad \ln w_{2 i}=X_{i} \beta_{2}+\delta_{2} m m_{i}+\varepsilon_{2 i}$ if $h i_{i}^{*} \leq 0$, where:

(5) $\quad I_{i}=1$ if $h i_{i}^{*}=Z_{i} \theta+v_{i}>0$ and $I_{i}=0$ if $h i_{i}^{*}=Z_{i} \theta+v_{i} \leq 0$

The vector: $h i_{i}^{*}$ is the latent variable that determines whether a particular female employee is hired by an employer who offers her health insurance coverage. What we observe, however, is the dichotomous variable: $I_{i}=1$ if $h i_{i}^{*}>0$ and $I_{i}=0$ otherwise. The vector $w_{1 i}$ represents the 
wage earned by woman $i$ working for an employer who offers health insurance, whereas $w_{2 i}$ is the wage earned by woman $i$ working for an employer who does not offers health insurance. The error terms in equations (3) through (5) are assumed to have a trivariate normal distribution with mean vector zero and a covariance matrix where the covariance between $\varepsilon_{1 i}$ and $\varepsilon_{2 i}$ is not defined as we never observe both $w_{1 i}$ and $w_{2 i}$ for a given individual. Therefore, as explained by Lokshin and Sajaia (2004), the model is identified by definition through these nonlinearities.

Yet, to improve the identification, the vector $Z$ includes all the characteristics thought to affect wages based on typical Mincer’s type specification (Mincer and Polachek, 1974) included in $X$, as well as a variable indicating the percentage of jobholders in the household. The fraction of jobholders in the household serves as an identifier for the equation modeling the likelihood of having a job that offers health insurance as we expect that variable to influence the respondent's choice of a job with or without health insurance, but not her/his wages. ${ }^{7}$ We, nonetheless, check the correlation of our instrument with the individual's choice of a job that offers health insurance -the endogenous regressor to be instrumented. The problem of "weak instruments" arises when either the instruments are weakly correlated with the endogenous regressor or the number of IVs is too large (Angrist and Krueger 2001). A simple F-test indicates that our IV is strongly correlated to the likelihood of being offered health insurance. ${ }^{8}$ Finally, because the likelihood of choosing a job that offers health insurance is being instrumented by one variable, we do not make use of over-identification tests to examine the

\footnotetext{
${ }^{7}$ This variable has also been used in other studies as a valid instrument for the choice of job made by respondents, e.g. Lokshin and Sajaia (2004).

${ }^{8}$ The F-test is given by: $F(1,19695)=10.96$, with Prob $>F=0.0009$ when we do not distinguish how many children the mother has (i.e. we simply include a motherhood dummy) and by: $F(1,19694)=6.13$ with $\quad$ Prob $>F=0.0133$ when we do (i.e. when we include dummies indicative of whether the mother has one child or two or more children).
} 
exogeneity of our instrument. ${ }^{9}$ To the extent that these tests have relatively low power in case of general misspecifications (e.g. Newey 1985) and serve to examine the exogeneity of each one of our instruments conditional on the other ones being valid, we defend our choice of instrument on theoretical reasons. In particular, based on human capital theory, wages are explained by human capital descriptors and other individual characteristics of the respondent following Mincer and Polachek's (1974) seminal work, but not by characteristics of other household members (i.e. who works and who does not), which are more likely to play a role in the individual's work decision instead, e.g. the likelihood of choosing a job that offers health insurance.

Equations (3)-(5) are estimated simultaneously through a full-information maximum likelihood method, making it possible to test with more clarity whether the motherhood wage gap is different for women with employer health insurance offers relative to women without such offers. A priori, we expect the motherhood wage gap to be larger for mothers who received health insurance offers at work; in other words, we would expect to see that: $\left|\delta_{1}\right|>\left|\delta_{2}\right|$. Incorporating the endogenous switching mechanism ought to have a substantial impact on estimates of the motherhood wage gap, as was found by Nielsen et al. (2004). Their estimation of the public versus private sector motherhood wage gap (akin to our analysis of the motherhood wage gap between women with health insurance coverage offers and those without) produced an estimated motherhood wage gap of 2.4 percent in the public sector and no statistically significant gap in the private sector. Incorporating the endogenous switching regression mechanism, public sector mothers received a child premium of 3 percent, whereas private sector mothers experienced a child penalty of 6 percent.

\section{Results}

${ }^{9}$ Nielsen et al. (2004) also rely on a single instrument in their endogenous (sector-specific) switching wage regression model. 


\section{A) Baseline Estimates}

Baseline estimation results of the motherhood wage gap are displayed in Table 3. This table presents the motherhood wage penalty resulting from a log wage regression estimated in three ways, measuring motherhood in two different ways. ${ }^{10}$ First, we estimate a simple ordinary least squares regression of the logarithm of wages earned by all working women, regardless of whether or not they are offered health insurance by their employers. This estimate is a replication of much previous research and serves as a point of comparison from which to start our discussion. The estimated motherhood wage gap from such a model in Panel A, Table 3, is approximately 6 percent, with the motherhood penalty associated with one child versus two or more children equaling 3 percent and 7 percent, respectively. These estimates fall well within the range reported in the existing literature. ${ }^{11}$

Subsequently, focusing on the question at hand in this paper, we stratify our sample of working women according to whether or not they are offered health insurance by their employers. Using these two sub-samples, we re-estimate the log wage regression in Panel A of Table 4. These results are displayed in Panels B and C of Table 3. Looking first at women with employment-based health insurance offers (Panel C), we see that mothers earn lower wages than non-mothers, based both on the single motherhood dummy variable and the combination dummy variables for motherhood. However, the evidence of a motherhood wage gap among working women lacking employment-based health insurance offers (Panel B) is much weaker. It is only

${ }^{10}$ Complete regression results from these baseline estimations are available from the authors upon request.

${ }^{11}$ Because there is no single norm in the literature regarding the measurement of motherhood, we report estimates throughout our analyses using two separate sets of regressions which rely on two different measurements of motherhood. The first is a single 0-1 dummy variable indicating motherhood, while the second is actual a combination of two dummy variables, the first indicating the presence of a single child in the family and the second indicating two or more children in the family. 
when we distinguish according to whether mothers have had one or two plus children that we find some evidence of a statistically significant (at the 5 percent level) motherhood wage gap. Specifically, mothers with two or more children lacking employment-based health insurance offers earn approximately 4.6 percent less than similar non-mothers, ceteris paribus. In contrast, among women with employment-based health insurance offers in Panel C, mothers earn an average of 5 percent less than non-mothers, with the wage penalties associated to having one and two plus children averaging out 4 percent and 6 percent, respectively.

In sum, from this simple regression approach, it appears that there exists a clear trade-off between wages and having an employment-based health insurance offer for mothers receiving such benefits, with the common estimates of the motherhood wage gap found in the existing literature being driven by the wage gap for mothers with employment-based health insurance offers. However, owing to endogeneity problems emerging, in part, from the self-selection of women into particular type of jobs, as well as owing to the different wage structure associated with jobs according to whether or not they offer health insurance, we turn to a more rigorous econometric analysis of the problem at hand.

\section{B) Estimates from the Endogenous Switching Regression Model}

Results from the endogenous switching regression model described in equations (3) through (5) are displayed in Tables 4 and 5, which only differ in how motherhood is measured. Our estimation approach in both tables corrects the standard errors to account for clustering at the individual level. Additionally, while the models are identified by definition through nonlinearities (see Lokshin and Sajaia, 2004), the health insurance offer equation includes all the characteristics thought to affect wages along with a variable indicative of the percentage of jobholders in the respondent's household to improve identification. Note that the coefficient 
associated with this instrument is positive, suggesting positive assortative mating, i.e., individuals likely to receive employer-provided health insurance coverage offers are likely to have partners with comparable quality job offers. Overall, the model offers a good specification, as suggested by the Log Likelihood and LR test of the independence of the equations in the model.

Focusing on the motherhood wage gap, which in Table 4 is captured by the single motherhood dummy and in Table 5 by the combination motherhood dummies, we find evidence of a motherhood wage gap for mothers in jobs with health insurance offers, even after accounting for this job sector self-selection. In contrast, we find no evidence of a motherhood wage gap among women in jobs lacking employer-based health insurance offers after taking into consideration their self-selection into such jobs. As a result, the motherhood wage penalty of mothers with an employer health insurance offer is significantly larger than for mothers without such an offer (i.e. as expected: $\left.\left|\delta_{1}\right|>\left|\delta_{2}\right|\right)$; furthermore, this difference seems to be driving the average estimates of the motherhood wage gap found in our baseline results and in other studies. Our finding is suggestive of a compensating wage differential story; namely, that mothers who obtain jobs in the "good" job sector are trading off wages for health insurance offers and it is this CWD trade-off that is driving the overall motherhood wage gap. This is consistent with the findings of both Felfe's (2007) results using German data and Nielsen et al.'s (2004) findings using Danish data. Note that this CWD argument for the sector-specific motherhood wage gap exists despite the results shown in Columns 1 of Tables 4 and 5 in which motherhood is associated with a lower overall likelihood of employment in the health insurance job sector.

Finally, the correlation coefficient Rho1 in both tables is negative and statistically different from zero, signaling that women in jobs offering health insurance would earn higher 
wages had they chosen jobs not offering such benefit. In other words, women offered health insurance at work pay a compensating wage differential for such a benefit, whereas women working for employers who do not offer health insurance do no better or worse than a random working mother from the sample. This evidence suggests further that the motherhood wage gap estimates much discussed in the economics literature originate, at least in part, from a compensating differential for employment-based health insurance.

The remaining coefficient estimates presented in Table 4 and Table 5 reveal some interesting differences according to whether or not women are offered health insurance at work. For example, age is a statistically positive predictor of wages for working women with health insurance offers but not for their counterparts lacking such offers. Mothers with health limitations suffer a much smaller wage penalty when they acquire "good" jobs (i.e., those with health insurance offers), than with suffer a penalty if they get "bad" jobs (4 percent versus 18 percent wage penalty). Additionally, mothers who reside in areas with relatively higher local unemployment rates earn lower wages much more so when employed in the "bad" job sector (3 percent versus 7 percent). Finally, residing in the South is associated with lower wages only in the case of "good" jobs, perhaps due to a weaker union presence in the South.

As is the case with all empirical research, the analysis carried out presents some caveats. We have chosen to focus on the self-selection of women into a particular type of job and, therefore, on the endogeneity of having an employment-based health insurance offer. As such, we have estimated an endogenous switching regression model to address these problems as well as the distinct wage structure characterizing jobs offering health insurance. However, owing to this model's complexity, we have not addressed two other issues sometimes addressed by the motherhood wage gap literature. First, we have not taken into account the endogeneity of 
motherhood. As noted by Amuedo-Dorantes and Kimmel (2005), it is difficult to find appropriate instruments for becoming a mother owing to the fact that motherhood and employment decisions are made by the same individual. In any event, it is worth noting that previous studies have shown that instrumenting for motherhood only serves to widen the motherhood wage gap estimates, not to diminish them.

Additionally, as discussed at the beginning of this study, a second concern in the motherhood wage gap literature is the role played by individual level heterogeneity. Several papers on the motherhood wage gap (including Anderson et al. (2002 and 2003), Waldfogel (1997 and 1998), and Budig and England (2001)) rely on panel data techniques to address the likely heterogeneity in their samples. We do not allow for individual level fixed effects owing to the complexity of incorporating this extension in the context of an endogeneous switching regression model. However, we do adjust our standard errors to allow for clustering at the individual level. Furthermore, it is worth noting that, to the extent that accounting for individual fixed effects does not appreciably alter the estimates of the motherhood wage gap (see, for example, Amuedo-Dorantes and Kimmel 2005), our results can be regarded as reliable evidence of the contribution of employment-based health insurance offers to the motherhood wage gap.

\section{Summary}

Many hypotheses have been offered to date as explanations for the observed wage gap between mothers and non-mothers. Inspired by the hedonic wage model, we hypothesize that relatively lower wages for mothers reflect a compensating wage differential that adjusts for a preference for the non-wage benefit of employer-provided health insurance coverage. We test this hypothesis by estimating an endogenous switching regression wage model in which the switching mechanism is the observed offer of employer health insurance coverage. We find that, 
once the endogeneity of the health insurance offer -partially originating in the self-selection of women into a particular type of job- is accounted for, mothers holding these "good" jobs earn less than their female non-mother counterparts, ceteris paribus. Thus, the much-reported motherhood wage gap appears to originate, at least in part, from a negative compensating wage differential arising from a relative preference on the part of mothers for an important component of non-wage compensation, namely, health insurance coverage. This finding prevails despite mothers' overall reduced likelihood of receiving offers of employer health insurance coverage. This conclusion has relevance for the policy discussion concerning the motherhood wage gap, as it suggests a different source of this wage differential and reinforces the importance of job sector choice in driving that gap. Additionally, our finding provides an explanation for the larger motherhood wage gap observed in the United States (relative to other developed countries) as noted by Todd (2001).

Where does this new empirical finding leave us? First, our findings, as well as those of Felfe (2007) and Nielsen et al. (2004), suggest that future studies of the role of motherhood in determining wages ought to focus on a broader assortment of job characteristics, not just wages. Increased availability of data sets including not only information on the offer of health insurance at work, but also on the generosity of the health plan, could be used to produce precise estimates of the wage-fringe trade-off in women's job choices. Second, a more explicit incorporation of individual level heterogeneity might improve our understanding of the role of motherhood in the structure of compensation packages and the trade-off between wage and non-wage compensation. In any event, it is apparent that the choice of job sector, as manifested in our case by the employer's offer of health insurance, plays an important role in wage determination, particularly for mothers. 


\section{References}

Adams, Scott J. 2007. "Health Insurance Market Reform and Employee Compensation: The Case of Pure Community Rating in New York,” Journal of Public Economics Vol. 91, No. 6, pp. 1119-1133.

Amuedo-Dorantes, Catalina and Jean Kimmel. 2005. "The Motherhood Wage Gap for Women in the United States: The Importance of College and Fertility Delay" Review of Economics of the Household, Vol. 3, No. 1, pp. 17-48.

Anderson, Deborah J., Melissa Binder and Kate Krause. 2003. "The Motherhood Wage Penalty Revisited: Experience, Heterogeneity, Work Effort and Work-Schedule Flexibility” Industrial and Labor Relations Review Vol. 56, No. 2 (January), pp. 273-294.

2002. “The Motherhood Wage Gap: Who Pays it and Why?” American Economic Review Papers and Proceedings, Vol. 92, No. 3 (May), pp. 354-58.

Angrist, J. D. and A. Krueger. 2001. "Instrumental Variables and the Search for Identification: From Supply and Demand to Natural Experiments” Journal of Economic Perspectives, Vol. 15, No. 4, pp. 69-85.

Atrostic, B.K. 1982. "The Demand for Leisure and Nonpecuniary Job Characteristics," The American Economic Review, Vol. 72, No. 3 (June), pp. 428-440.

Blackburn, McKinley L., David E. Bloom, and David Neumark. 1990. "Fertility Timing, Wages and Human Capital.” NBER Working Paper No. 3422, August.

Budig, Michelle J. and Paula England. 2001. “The Wage Penalty for Motherhood,” American Sociological Review, Vol. 66, (April), pp. 204-225.

Currie, Janet and B.C. Madrian. 1999. "Health Insurance and the Labor Market," Handbook of Labor Economics, Vol. 3C, edited by Orley Ashenfelter and David Card, Elsevier: New York, pp. 3309-3416.

Felfe, Andrea Christina. 2007. “The child penalty-A compensating wage differential?” unpublished manuscript, Universitat Pompeu Fabra (July).

Filer, Randall K. "Male-Female Wage Differences: The Importance of Compensating Differentials,” Industrial and Labor Relations Review, Vol. 38, No. 3 (April), pp. 426-437.

Gruber, Jonathan. 1994. "The Incidence of Mandated Maternity Benefits," The American Economic Review, Vol. 84, No. 3 (June), pp. 622-641.

Hill, Martha. 1979. "The Wage Effects of Marital Status and Children.” The Journal of Human Resources, Vol. 14, pp. 579-94. 
Lehrer, Steven F. and Nuno Sousa Pereira. 2007. "Worker sorting, compensating differentials and health insurance: Evidence from displaced workers," Journal of Health Economics Vol. 26, pp. 1034-56.

Levy, Helen. 2006. “Health Insurance and the Wage Gap,” NBER Working Paper No. 11975, January.

Lokshin, Michael and Zurab Sajaia. 2004. "Maximum Likelihood Estimation of Endogenous Switching Regression Models” The Stata Journal, Vol. 4, No. 3, pp. 282-289.

Maddala, G.S. 1983. Limited-dependent and Qualitative Variables in Econometrics, New York: Cambridge University Press.

McCrate, Elaine. 2005. "Flexible Hours, Workplace Authority, and Compensating Wage Differentials in the US," Feminist Economics, Vol. 11, No. 1 (March), pp. 11-39.

Mincer, Jacob and S. Polachek. 1974. "Family Investments in Human Capital: Earnings of Women” Journal of Political Economy (Supplement), Vol. 82: S76-S108.

Monheit, Alan C. and Jessica Primoff Vistnes. 1999. "Health Insurance Availability at the Workplace: How Important are Worker Preferences?” The Journal of Human Resources, Vol. 34, No. 2 (Winter), pp. 770-85.

Nielsen, Helena Skyt, Marianne Simonsen and Mette Verner. 2004. "Does the Gap in FamilyFriendly Policies Drive the Family Gap?” Scandinavian Journal of Economics, Vol. 106, No. 4 (December), pp. 721-44.

Neumark, David and Sanders Korenman. 1992. "Marriage, Motherhood, and Wages,” Journal of Human Resources, Vol. 27, Issue 2 (Spring), pp. 233-255.

Newey, W. 1985. "Generalized Method of Moments Specification Testing” Journal of Econometrics, Vol. 29, pp. 229-256.

Sheiner, Louise. 1999. "Health Care Costs, Wages, and Aging," FEDS Discussion Paper No. 99-19 (January), 35 pages.

Taniguchi, Hiromi. 1999. “The Timing of Childbearing and Women's Wages,” Journal of Marriage and the Family, Vol. 61 (November), pp. 1008-1019.

Todd, Erin L. 2001. “Educational Attainment and Family Gaps in Women’s Wages: Evidence from Five Industrialized Countries,” Luxembourg Income Study Working Paper No. 246, January.

Waldfogel, Jane. 1997. "The Effects of Children on Women's Wages,” American Sociological Review, Vol. 62, pp. 209-217. 
1998. "The Family Gap for Young Women in the United States and Britain: Can Maternity Leave Make a Difference?” Journal of Labor Economics, Vol. 16, pp. 505-545.

Woodbury, Stephen, A. 1983. "Substitution between Wage and Non-wage Benefits," The American Economic Review, Vol. 73, No. 1 (March), pp. 166-182. 
Table 1

Variables, Means, and Standard Deviations as of 2004

\begin{tabular}{|c|c|c|c|c|c|}
\hline \multirow{2}{*}{ Variable Name } & \multirow{2}{*}{ Variable Description } & \multicolumn{2}{|c|}{ Without HI } & \multicolumn{2}{|c|}{ With HI } \\
\hline & & Mean & S.D. & Mean & S.D. \\
\hline Real Hourly Wage & Real hourly wages (1984-1986 dollars) & 5.87 & 4.21 & 9.68 & 11.18 \\
\hline Age & Age of respondent & 43.21 & 2.14 & 43.09 & 2.25 \\
\hline White & Race dummy & 0.67 & 0.47 & 0.62 & 0.49 \\
\hline Hispanic & Race dummy & 0.06 & 0.25 & 0.06 & 0.23 \\
\hline Black & Race dummy & 0.27 & 0.44 & 0.32 & 0.47 \\
\hline Health Limitations & Dummy variable indicative of health limitations & 0.12 & 0.32 & 0.05 & 0.22 \\
\hline Married & Marital status dummy & 0.60 & 0.49 & 0.55 & 0.50 \\
\hline Motherhood & Dummy equal to 1 if woman is a mother & 0.75 & 0.43 & 0.73 & 0.45 \\
\hline One child & Dummy equal to $q$ if woman only has one child & 0.29 & 0.45 & 0.28 & 0.45 \\
\hline Two or more children & Dummy equal to 1 if woman has two kids or more & 0.46 & 0.50 & 0.44 & 0.50 \\
\hline Less than High School & Educational attainment dummy & 0.13 & 0.34 & 0.06 & 0.24 \\
\hline High School & Educational attainment dummy & 0.44 & 0.50 & 0.42 & 0.49 \\
\hline Some College & Educational attainment dummy & 0.27 & 0.45 & 0.31 & 0.46 \\
\hline College & Educational attainment dummy & 0.16 & 0.37 & 0.21 & 0.41 \\
\hline Tenure & Tenure in weeks & 222.47 & 251.90 & 403.66 & 342.40 \\
\hline Professional \& Managers & Occupation dummy & 0.29 & 0.46 & 0.40 & 0.49 \\
\hline Sales & Occupation dummy & 0.05 & 0.21 & 0.04 & 0.20 \\
\hline Clerical & Occupation dummy & 0.22 & 0.41 & 0.29 & 0.45 \\
\hline Craftsmen & Occupation dummy & 0.04 & 0.20 & 0.03 & 0.16 \\
\hline Operatives & Occupation dummy & 0.09 & 0.28 & 0.09 & 0.29 \\
\hline Laborers & Occupation dummy & 0.04 & 0.20 & 0.02 & 0.13 \\
\hline Farm & Occupation dummy & 0.01 & 0.08 & 0.01 & 0.03 \\
\hline Services & Occupation dummy & 0.26 & 0.44 & 0.12 & 0.33 \\
\hline Part-time Work & Part-time work dummy & 0.30 & 0.46 & 0.15 & 0.36 \\
\hline Urban & Equal to 1 if respondent lives in an urban area & 0.75 & 0.47 & 0.81 & 0.45 \\
\hline High Unemployment Rate & Equal to 1 if respondent lives in high unemployment area & 0.02 & 0.15 & 0.02 & 0.15 \\
\hline North Central & Regional dummy & 0.23 & 0.42 & 0.24 & 0.43 \\
\hline Northeast & Regional dummy & 0.17 & 0.37 & 0.18 & 0.38 \\
\hline South & Regional dummy & 0.43 & 0.50 & 0.42 & 0.49 \\
\hline West & Regional dummy & 0.17 & 0.38 & 0.16 & 0.37 \\
\hline \% w/Employed HH Members & Percentage of employed household members & 0.78 & 0.64 & 0.80 & 0.62 \\
\hline
\end{tabular}


Table 2

Difference-in-Difference Estimates

\begin{tabular}{|c|c|c|c|}
\hline Panel A: & & & \\
\hline & Mothers & Non-Mothers & $\Delta$ (Mothers vs. Non-mothers) \\
\hline Without HCI & $1.51(0.61)$ & $1.52(0.71)$ & -0.0139 (0.0193) \\
\hline With HCI & $1.90(0.57)$ & $2.04(0.57)$ & $-0.1483(0.0096)^{* * *}$ \\
\hline Diff-in-diff & - & - & $-0.1344(0.0215)^{* * *}$ \\
\hline \multicolumn{4}{|l|}{ Panel B: } \\
\hline & Mothers with One Kid & Non-Mothers & $\Delta$ (Mothers with One Kid vs. Non-mothers) \\
\hline Without HCI & $1.55(0.59)$ & $1.52(0.71)$ & $0.0260(0.0230$ \\
\hline With HCI & $1.93(0.56)$ & $2.04(0.57)$ & $-0.1137(0.0119)^{* * *}$ \\
\hline Diff-in-diff & - & - & $-0.1397(0.0259)^{* * *}$ \\
\hline \multicolumn{4}{|l|}{ Panel C: } \\
\hline & Mothers with Two Plus Kids & Non-Mothers & $\Delta$ (Mothers with Two Plus Kids vs. Non-mothers) \\
\hline Without HCI & $1.49(0.61)$ & $1.52(0.71)$ & $-0.0296(0.0200$ \\
\hline With HCI & $1.88(0.58)$ & $2.04(0.57)$ & $-0.1674(0.0105)^{* * *}$ \\
\hline Diff-in-diff & - & - & $-0.1377(0.0226)^{* * *}$ \\
\hline
\end{tabular}

Notes: Standard errors are in parentheses. *** Signifies statistically different from zero at the 1 percent level or better. 
Table 3

Baseline Estimates of the Motherhood Wage Gap

Panel A: Full Sample of Working Women

\begin{tabular}{lcccc}
\hline Key Independent Variables & Coefficient & S.E. & \multicolumn{2}{c}{ Regression Fit Statistics } \\
Motherhood & $-0.0570^{* * *}$ & 0.0086 & $\mathrm{~N}=19295$ & $\mathrm{~F}(25,19269)=327.77$ \\
& & & & \\
One Child & $-0.0308^{* * *}$ & 0.0103 & $\mathrm{~N}=19295$ & $\mathrm{~F}(26,19268)=316.31$ \\
Two Plus Children & $-0.0746^{* * *}$ & 0.0094 & & \\
& & & \\
\hline
\end{tabular}

Panel B: Working Women Lacking Employment-Based Health Insurance Offers

\begin{tabular}{lcccc}
\hline Key Independent Variables & Coefficient & S.E. & \multicolumn{2}{c}{ Regression Fit Statistics } \\
Motherhood & -0.0267 & 0.0196 & $\mathrm{~N}=4953$ & $\mathrm{~F}(25,4927)=52.83$ \\
& & & & \\
One Child & 0.0127 & 0.0238 & $\mathrm{~N}=4953$ & $\mathrm{~F}(26,4926)=51.20$ \\
Two Plus Children & $-0.0463^{* *}$ & 0.0207 & & \\
& & & & \\
\hline
\end{tabular}

Panel C: Working Women with Employment-Based Health Insurance Offers

\begin{tabular}{lcccc}
\hline Key Independent Variables & Coefficient & S.E. & \multicolumn{2}{c}{ Regression Fit Statistics } \\
\hline Motherhood & $-0.0510^{* * *}$ & 0.0093 & $\mathrm{~N}=14282$ & $\mathrm{~F}(25,14256)=227.86$ \\
& & & & \\
One Child & $-0.0378^{* * *}$ & 0.0111 & $\mathrm{~N}=18334$ & $\mathrm{~F}(26,14255)=219.34$ \\
Two Plus Children & $-0.0607^{* * *}$ & 0.0103 & &
\end{tabular}

Notes: All equations include a constant. *** Signifies statistically different from zero at the $1 \%$ level or better and **at the $5 \%$ level or better. 
Table 4

Motherhood Wage Gap by Offer of Employer-Provided Health Care Insurance

(First Motherhood Specification)

\begin{tabular}{|c|c|c|c|c|c|c|}
\hline \multirow[t]{2}{*}{ Independent Variables } & \multicolumn{2}{|c|}{$\begin{array}{l}\text { Health Insurance Offer } \\
\text { Equation }\end{array}$} & \multicolumn{2}{|c|}{$\begin{array}{c}\text { Wage Equation for Women } \\
\text { with Health Insurance }\end{array}$} & \multicolumn{2}{|c|}{$\begin{array}{l}\text { Wage Equation for Women } \\
\text { without Health Insurance }\end{array}$} \\
\hline & Coefficient & S.E. & Coefficient & S.E. & Coefficient & S.E. \\
\hline Age & $0.1413 * * *$ & 0.0397 & $0.0386 * *$ & 0.0159 & 0.0231 & 0.0388 \\
\hline Age Squared & $-0.0019 * * *$ & 0.0006 & $-0.0004^{* *}$ & 0.0002 & -0.0003 & 0.0005 \\
\hline Hispanic & -0.0389 & 0.0802 & -0.0072 & 0.0299 & 0.0102 & 0.0586 \\
\hline Black & $0.1329 * * *$ & 0.0421 & $-0.1016 * * *$ & 0.0165 & $-0.0986 * * *$ & 0.0303 \\
\hline Health Limitations & $-0.2258 * * *$ & 0.0576 & $-0.0443^{*}$ & 0.0300 & $-0.1835 * * *$ & 0.0489 \\
\hline Married & 0.0122 & 0.0342 & $0.0192 *$ & 0.0129 & $0.0406 * *$ & 0.0211 \\
\hline Motherhood & $-0.1584 * * *$ & 0.0455 & $-0.0328 * * *$ & 0.0166 & -0.0163 & 0.0366 \\
\hline Less than High School & $-0.2903^{* * *}$ & 0.0555 & $-0.1252 * * *$ & 0.0271 & $-0.1090 * *$ & 0.0501 \\
\hline Some College & $0.0821^{* * *}$ & 0.0408 & $0.1561 * * *$ & 0.0153 & $0.1363^{* * *}$ & 0.0254 \\
\hline College & $0.0958 * *$ & 0.0562 & $0.3901 * * *$ & 0.0231 & $0.3575 * * *$ & 0.0444 \\
\hline Tenure & $0.0030 * * *$ & 0.0002 & $0.0004 * * *$ & 0.0001 & $0.0008 * *$ & 0.0004 \\
\hline Tenure Squared & $1.84 \mathrm{e}-06 * * *$ & $1.75 e-07$ & $-1.36 \mathrm{e}-07$ & $1.05 \mathrm{e}-07$ & $0.0000 * *$ & 0.0000 \\
\hline Professional \& Managers & $0.6851 * * *$ & 0.0472 & $0.2467 * * *$ & 0.0420 & $0.2311^{* * * *}$ & 0.0859 \\
\hline Sales & $0.4068 * * *$ & 0.0705 & $0.1780 * * *$ & 0.0428 & 0.0473 & 0.0696 \\
\hline Clerical & $0.6021^{* * *}$ & 0.0480 & $0.0961 * * *$ & 0.0372 & 0.0698 & 0.0720 \\
\hline Craftsmen & $0.4332 * * *$ & 0.0550 & $0.1365 * * *$ & 0.0313 & 0.0345 & 0.0538 \\
\hline Operatives & $0.7326 * * *$ & 0.0670 & 0.0247 & 0.0420 & -0.0029 & 0.0828 \\
\hline Laborers & $0.4052 * * *$ & 0.0869 & -0.0185 & 0.0357 & $-0.1686^{* *}$ & 0.0913 \\
\hline Farm & $-0.7576^{* * *}$ & 0.2425 & 0.1617 & 0.1565 & -0.0250 & 0.1259 \\
\hline Part-time Work & $-0.5508 * * *$ & 0.0299 & 0.0344 & 0.0300 & 0.0373 & 0.0696 \\
\hline Urban & 0.0480 & 0.0381 & $0.0575 * * *$ & 0.0148 & $0.1003 * * *$ & 0.0204 \\
\hline High Unemployment Rate & $-0.1065^{* *}$ & 0.0453 & $-0.0229 *$ & 0.0178 & $-0.0700 * * *$ & 0.0289 \\
\hline Northeast & 0.0172 & 0.0564 & $0.1595 * * *$ & 0.0222 & $0.1689 * * *$ & 0.0336 \\
\hline South & $0.1229 * * *$ & 0.0455 & $-0.0361^{* *}$ & 0.0185 & -0.0073 & 0.0343 \\
\hline West & $0.1382 * * *$ & 0.0565 & $0.0896 * * *$ & 0.0228 & $0.1195 * * *$ & 0.0403 \\
\hline \% of Employed HH Members & $0.1033^{* * *}$ & 0.0375 & - & - & - & - \\
\hline \multicolumn{7}{|l|}{ Regression Fit Statistics } \\
\hline $\mathrm{N}$ & \multicolumn{6}{|c|}{19235} \\
\hline Log likelihood & \multicolumn{6}{|c|}{-23064.571} \\
\hline Rho1 Coefficient & \multicolumn{6}{|c|}{$-0.4347 * * *$} \\
\hline (S.E.) & \multicolumn{6}{|c|}{$(0.1768)$} \\
\hline Rho2 Coefficient & \multicolumn{6}{|c|}{-0.1191} \\
\hline (S.E.) & \multicolumn{6}{|c|}{$(0.3050)$} \\
\hline LR test of indep. eqns. : & \multicolumn{6}{|c|}{ Chi2 (1) = 4.64} \\
\hline Prob $>$ Chi2 & \multicolumn{6}{|c|}{0.0312} \\
\hline
\end{tabular}

Notes: All equations include a constant. *** Signifies statistically different from zero at the $1 \%$ level or better, $* *$ at the $5 \%$ level or better and *at the $10 \%$ level or better. Reference categories: White, High School, Services, and North Central. 
Table 5

Motherhood Wage Gap by Offer of Employer-Provided Health Care Insurance (Second Motherhood Specification)

\begin{tabular}{|c|c|c|c|c|c|c|}
\hline \multirow[t]{2}{*}{ Independent Variables } & \multicolumn{2}{|c|}{$\begin{array}{c}\text { Health Insurance Offer } \\
\text { Equation }\end{array}$} & \multicolumn{2}{|c|}{$\begin{array}{l}\text { Wage Equation for Women } \\
\text { with Health Insurance }\end{array}$} & \multicolumn{2}{|c|}{$\begin{array}{l}\text { Wage Equation for Women } \\
\text { without Health Insurance }\end{array}$} \\
\hline & Coefficient & S.E. & Coefficient & S.E. & Coefficient & S.E. \\
\hline Age & $0.1544 * * *$ & 0.0402 & $0.0399 * *$ & 0.0163 & 0.0297 & 0.0362 \\
\hline Age Squared & $-0.0021 * * *$ & 0.0006 & $-0.0005^{* *}$ & 0.0002 & -0.0004 & 0.0005 \\
\hline Hispanic & -0.0318 & 0.0780 & -0.0066 & 0.0299 & 0.0130 & 0.0592 \\
\hline Black & $0.1407 * * *$ & 0.0423 & $-0.1008 * * *$ & 0.0167 & $-0.0944 * * *$ & 0.0281 \\
\hline Health Limitations & -0.2329 & 0.0570 & $-0.0451^{*}$ & 0.0302 & $-0.1889 * * *$ & 0.0480 \\
\hline Married & 0.0217 & 0.0342 & $0.0201^{*}$ & 0.0130 & $0.0461^{* * *}$ & 0.0206 \\
\hline One Child & $-0.0877 * *$ & 0.0477 & $-0.0280 * * *$ & 0.0171 & 0.0174 & 0.0319 \\
\hline Two Plus Children & $-0.2195 * * *$ & 0.0513 & $-0.0373 * * *$ & 0.0193 & -0.0362 & 0.0350 \\
\hline Less than High School & $-0.2859 * * *$ & 0.0556 & $-0.1254 * * *$ & 0.0272 & $-0.1097 * * *$ & 0.0421 \\
\hline Some College & $0.0779 * *$ & 0.0408 & $0.1559 * * *$ & 0.0153 & $0.1361^{* * *}$ & 0.0250 \\
\hline College & $0.0888 *$ & 0.0563 & $0.3895^{* * *}$ & 0.0232 & $0.3569 * * *$ & 0.0431 \\
\hline Tenure & $0.0030 * * *$ & 0.0002 & $0.0004^{* * *}$ & 0.0001 & $0.0008^{* * *}$ & 0.0003 \\
\hline Tenure Squared & $-1.82 \mathrm{e}-06^{* * *}$ & $1.75 e-07$ & $-1.37 e-07$ & $1.05 \mathrm{e}-07$ & $-6.85 \mathrm{e}-07 * * *$ & 2.69e-07 \\
\hline Professional \& Managers & $0.6835^{* * *}$ & 0.0472 & $0.2475^{* * *}$ & 0.0426 & $0.2377^{* * *}$ & 0.0633 \\
\hline Sales & $0.4028 * * *$ & 0.0706 & $0.1783^{* * *}$ & 0.0430 & 0.0492 & 0.0601 \\
\hline Clerical & $0.6008 * * *$ & 0.0480 & $0.0967 * * *$ & 0.0377 & $0.0766^{*}$ & 0.0525 \\
\hline Craftsmen & $0.4289 * * *$ & 0.0550 & $0.1373^{* * *}$ & 0.0316 & 0.0354 & 0.0417 \\
\hline Operatives & $0.7347 * * *$ & 0.0673 & 0.0259 & 0.0427 & 0.0052 & 0.0621 \\
\hline Laborers & $0.4063^{* * *}$ & 0.0869 & -0.0180 & 0.0360 & $-0.1638 * * *$ & 0.0836 \\
\hline Farm & $-0.7566 * * *$ & 0.2405 & 0.1554 & 0.1568 & -0.0246 & 0.1189 \\
\hline Part-time Work & $-0.5479 * * *$ & 0.0299 & 0.0337 & 0.0303 & $0.0332 * * *$ & 0.0509 \\
\hline Urban & 0.0453 & 0.0381 & $0.0574 * * *$ & 0.0148 & $0.0997 * * *$ & 0.0201 \\
\hline High Unemployment Rate & $-0.1022 * * *$ & 0.0453 & -0.0225 & 0.0177 & $-0.0697 * * *$ & 0.0270 \\
\hline Northeast & 0.0141 & 0.0565 & $0.1598 * * *$ & 0.0222 & 0.1654 & 0.0332 \\
\hline South & $0.1148^{* * *}$ & 0.0457 & $-0.0363 * * *$ & 0.0185 & $-0.0094 * * *$ & 0.0318 \\
\hline West & $0.1337 * * *$ & 0.0566 & $0.0899 * * *$ & 0.0228 & 0.1179 & 0.0382 \\
\hline \% of Employed HH Members & $0.0858 * *$ & 0.0378 & - & - & - & - \\
\hline \multicolumn{7}{|l|}{ Regression Fit Statistics } \\
\hline $\mathrm{N}$ & \multicolumn{6}{|c|}{19235} \\
\hline Log likelihood & \multicolumn{6}{|c|}{-30121.851} \\
\hline Rho1 Coefficient & \multirow{2}{*}{\multicolumn{6}{|c|}{$\begin{array}{c}-0.4281^{* * *} \\
(0.1818)\end{array}$}} \\
\hline (S.E.) & & & & & & \\
\hline Rho2 Coefficient & \multicolumn{6}{|c|}{-0.0944} \\
\hline (S.E.) & \multicolumn{6}{|c|}{$(0.2138)$} \\
\hline LR test of indep. eqns. : & \multicolumn{6}{|c|}{ Chi2 $(1)=4.35$} \\
\hline Prob $>$ Chi2 & \multicolumn{6}{|c|}{0.0371} \\
\hline
\end{tabular}

Notes: All equations include a constant. *** Signifies statistically different from zero at the $1 \%$ level or better, **at the $5 \%$ level or better and *at the $10 \%$ level or better. Reference categories: White, High School, Services, and North Central. 